\title{
The role of 3D digital applications in Manual Therapy Education - A scoping review
}

Kesava Kovanur Sampath ( $\sim$ kesava.sampath@wintec.ac.nz )

Ashokan Arumugam

Gwendolen Jull

\section{Systematic Review}

Keywords: Manual Therapy Education, 3D digital Applications, Virtual Reality, Augmented Reality, Palpation Skills, Haptic Feedback

Posted Date: December 30th, 2021

DOI: https://doi.org/10.21203/rs.3.rs-1178829/v1

License: @ (i) This work is licensed under a Creative Commons Attribution 4.0 International License. Read Full License 


\section{Abstract}

Background: Currently, teaching methods for developing complex physical assessment and palpation skills in manual therapy is challenging for both learners and educators. 3D digital technologies such as virtual reality (VR), augmented reality (AR) and mixed reality may facilitate and/or address these challenges. However, their current usage and/or role in improving learning outcomes in manual therapy education is still largely unknown.

Methods: The following electronic databases were searched from Jan 2005 to April 2021: PubMed, Cumulative Index to Nursing and Allied Health Literature (CINAHL), Physiotherapy Evidence Database (PEDro), Science Direct and Google Scholar. Two independent reviewers reviewed the articles retrieved from the databases to assess for eligibility. Studies of any methodology (quantitative, qualitative and mixed methods) that investigated the use or application of the 3D digital applications were included in the review. Primary outcomes included any outcome related to learning based on the updated Blooms taxonomy. Narrative synthesis was used to synthesise data from the included studies.

Results: A total of 4 articles were included in the final review. The main findings were classified into the following key concepts: (1) perception of tissue stiffness, (2) improved student self-efficacy in performing MT techniques, and (3) barriers and facilitators for utilizing 3D technologies. All included outcomes met understanding, applying, analysing and evaluating levels of Blooms taxonomy; however, no outcomes met the 'creating' level of Bloom's taxonomy.

Discussion: Our review found that there are no AR, VR or mixed applications that specifically serve the needs of MT education in relation to joint motion assessment, but applications are available that can be readily used or potentially adapted to train skills of tissue palpation. . Therefore, future studies are required to investigate the sophisticated requirements to teach/learn complex manual techniques for which palpation skills may be mandatory.

\section{Background}

3D digital applications such as virtual reality (VR), augmented reality (AR) and mixed reality technologies have been around for decades, with their use extended to several applied fields, amongst others, teaching and learning (Hamilton, McKechnie, Edgerton, \& Wilson, 2020). These systems often adapt virtual $3 \mathrm{D}$ visualizations to make difficult ideas more comprehensible by mimicking real-life scenarios. An AR system combines or "supplements" real world objects with virtual objects or superimposed information (Brigham, 2017) while in a VR system, the user is completely immersed inside a virtual environment (VE) (Hamilton et al., 2020). Evidence indicates that AR visualization in educational settings can improve task completion times, lead to fewer errors and improve student's motivation to learn (Khan, Johnston, \& Ophoff, 2019).

Students of manual therapy (MT) are required to develop complex clinical skills such as clinical reasoning, manual/physical assessments, palpation and patient management which includes skilled hands-on treatment (Michels, Evans, \& Blok, 2012). The process of learning clinical manual therapy skills usually incorporates the widely accepted 'See one, do one, teach one' approach, where students learn by observing an expert clinician/tutor performing the techniques on a student, a plastic anatomical model, or a patient (Bugaj \& Nikendei, 2016; Easton, Stratford-Martin, \& Atherton, 2012). The underlying assumption of such an approach is that trainees can become increasingly independent after observing an expert clinician or teacher for a few times (Kotsis \& Chung, 2013). Nevertheless, the 'See one, do one, teach one' approach has been criticized as an inadequate method in maintaining required patient safety standards because of the lack of supervision, reflection on action, performance evaluation and structured feedback (Lenchus, 2010; Rodriguez-Paz et al., 2009).

Haptics refers to the sense of touch, including both tactile and kinaesthetic perceptions/feedback of an object. Various haptic devices are commercially available; e.g., the Geomagic Touch haptic device, the Phantom Omni, the Falcon (Novint, USA) or the Sigma.7 (Force Dimension, Switzerland), to name a few. Some grounded haptic devices (e.g., Mater-Finger-2) have been designed specifically to support fingers which can be operated using the index finger and the thumb to grasp virtual objects and can also provide 6-DOF (Degrees-of-Freedom) (Monroy, Oyarzabal, Ferre, Campos, \& Barrio, 2008; Pacchierotti, Chinello, Malvezzi, Meli, \& Prattichizzo, 2012). The addition of haptic feedback in VR environments creates more realistic scenarios, while providing trainees with a safe environment in which they can develop their skills (Kirkman et al., 2014). It is through palpation (diagnosis through touch) that a clinician/student examines muscles in spasm and tissue abnormality which contributes important information to clinical reasoning, diagnosis and treatment in MT (Loh et al., 2015; Tong et al., 2018). Hence, it is possible that 3D digital technologies may enhance MT education relevant to E-learning; e.g., landmark palpation and localization, active and passive physiological movement assessment, and skills relevant to joint mobilization and manipulation such as the perception of tissue compliance. However, the use of 3D digital technologies (such as AR, VR and mixed realities) in improving learning outcomes in MT education is still largely unknown.

Scoping reviews are a form of knowledge synthesis, which incorporate a range of study designs to comprehensively summarize and synthesize evidence with the aim of informing practice (Arksey \& O'Malley, 2005). We considered a scoping review as the most appropriate method as little is known about the current usage of 3D digital technologies in MT education. The aims of the current scoping review were to: 1) Summarize the literature on the current usage of threedimensional (3D) digital applications (emulating virtual, augmented or mixed reality environments) in manual therapy education to improve any outcome relevant to learning of manual therapy by students, clinicians and academics; (2) Synthesise the literature on facilitators and barriers for using 3D digital applications as an educational tool for manual therapy.

\section{Methods}

The Arksey and O'Malley framework (Arksey \& O'Malley, 2005) and Joanna Briggs Institute (JBI) recommendations (Peters et al., 2020) were followed to conduct this scoping review. This protocol is reported in accordance with the preferred reporting items for systematic reviews and meta-analysis extension for scoping reviews (PRISMA-ScR) checklist.

\section{Operational definitions}


Manual examination is operationally defined as a passive examination of joint motion which tests for displacement and tissue resistance to displacement (i.e., tissue compliance akin to stress/strain properties) (Huijbregts, 2011). Perception of tissue compliance through palpation is an integral part of this examination method.

Manual therapy treatment is operationally defined as skilled hands-on intervention intended to improve tissue extensibility, increase range of motion of the joint complex, and mobilize or manipulate soft tissues and joints.

Digital applications are operationally defined as software applications that are compatible with mobiles (smartphones), computers, tablets, iPads, headmounted display, websites, or similar technological devices/platforms.

Augmented reality (AR) refers to the integration of the actual world with digital information about it. Actual objects and people cast an information shadow: an aura of data which, when captured and processed intelligently, can offer extraordinary value to consumers. Augmented reality uses technology to make such a layer of information accessible to people to blend one's perception of the actual world with digital content about it generated by computer software (Brigham, 2017; Farshid, Paschen, Eriksson, \& Kietzmann, 2018).

Virtual reality (VR) refers to complete, 3D virtual representations of the actual world or of objects within it. Full immersion is a unique aspect of VR (Farshid et al., 2018).

Mixed reality (MR) refers to the merging of real-world virtual constructs with computer-generated constructs that are either real or possible. MR combines aspects of the actual reality--the physical world around us-- with the power of virtual reality. It also combines what's real with what's possible (Brigham, 2017; Farshid et al., 2018).

Degrees of Freedom (DOF) is operationally defined as the number of different ways they can move or create forces. A simple haptic device has 1 DOF. Complex haptic devices that can move anywhere in space $(x, y, z)$ and create forces in any direction have 3 DOF. In addition to 3 DOF, if a haptic device can also track rotations and create rotational forces (torques) such as roll, pitch, and yaw; then it would be considered a device with 6 DOF.

\section{Eligibility criteria Inclusion criteria:}

Studies were included if they meet the following criteria.

Participants - students in healthcare professions, clinicians, academics, physiotherapists, manual therapists, manipulative therapists, osteopaths, and chiropractors.

Interventions - education of manual therapy skills or skill components (e.g., tissue palpation) delivered through 3D digital applications emulating augmented, virtual or mixed reality environments.

Comparators - studies were included without and with a comparator group (randomized/controlled clinical trials). Comparators could be any other method of manual therapy education (computer-based education material, face-to-face teaching, laboratory-based hands-on techniques, two-dimensional pictures, audiovisual materials, printed handouts, etc.)

Outcomes - primary outcomes included any outcome related to learning based on the updated the Blooms taxonomy, i.e., remembering, understanding, applying, analysing, evaluating and/or creating manual therapy skills (Ramirez, 2017). The learning outcomes could be assessed using objective structured practical examination (OSPE), objective structured clinical examination (OSCE) or observation of student performance with or without recorded videos.

Secondary outcomes included questionnaires, surveys or qualitative assessment of participant's perception, preferences, satisfaction, barriers and facilitators, and the usage of digital technologies for MT education and/or clinical practice.

Type of studies - randomized clinical trials, controlled clinical trials, quasi-experimental studies, case-series, cross-sectional, qualitative and mixed-methods studies.

Study setting - studies must have taken place in an educational, laboratory, classroom or clinical setting; studies done in any health profession that have direct and indirect implications for teaching MT assessment and treatment.

\section{Exclusion criteria:}

Studies were excluded if: (1) a 3D digital application was not used in an educational context for teaching MT skills; (2) classroom/lab-based teaching or other technologies (e.g., videos) excluding 3D digital applications, were used as the sole intervention for MT education; (3) digital applications incorporating 3D AR, VR or MR applications were used for teaching subjects/courses other than manual therapy; and (4) studies were published in any language other than English. Electronic databases

The following electronic databases were searched from Jan 2005 to April 2021: PubMed, Cumulative Index to Nursing and Allied Health Literature (CINAHL), Physiotherapy Evidence Database (PEDro), Science Direct and Google Scholar. The reference lists of all included studies, following screening, were also checked for any other relevant citations. 


\section{Identifying relevant studies (search strategy)}

A systematic search strategy was developed to locate studies relevant under three key domains: participants (manual therapy students and practitioners), interventions (digital applications), and outcomes (manual therapy knowledge/skills). A combination of keywords using the Boolean operators "OR" and "AND" within and between each of the key domains respectively was undertaken (Table 1). A pilot search was conducted independently by one reviewer and the retrieved articles were screened independently by two reviewers (KSK and AA).

Following the pilot search, eligibility criteria for the inclusion of relevant studies were reviewed and the search strategy was refined iteratively. A refined final search strategy was run by one reviewer to identify relevant studies.

Articles obtained by the systematic search were exported and saved into a reference management software program (EndNote X7 Thomson Corporation). Titles of the retrieved articles were screened for relevance after removing duplicates. Relevant abstracts were screened followed by retrieval of the full text of articles meeting the inclusion criteria. The screening procedure was conducted independently by two reviewers (KSK and AA). Disagreements were resolved by discussion; if no agreement could be reached, a third reviewer (GJ) was consulted to reach a consensus.

\section{Data Extraction}

The research team collectively decided which data/variables to extract. A data charting table/form was used to standardise this procedure. Data were extracted by one reviewer (KSK) and verified by another reviewer (AA). A third reviewer (GJ) was consulted in case of any disagreement.

\section{Results \\ Search results}

The electronic search yielded a total of 660 articles. Following the removal of duplicates, 563 articles were retained for further screening. After title, abstract, and full-text screening, 4 studies (Howell, Conatser, Williams, Burns, \& Eland, 2008; Khaled et al., 2004; Tong et al., 2018; Ullrich \& Kuhlen, 2012) were included for final synthesis (Fig. 1).

\section{Description of Included Studies}

A summary of the studies included is presented in Table 2. In total, 423 participants contributed to the findings. Participants were diverse and included students (osteopathic, medical, anaesthesiology), clinicians (anaesthesiology), and academics/teachers (medical). The 3D technology (intervention) commonly used was VR applications with haptic feedback and VR with magnetic levitation device. The main outcome measure across all studies was palpation of tissue compliance and user satisfaction. However, it has to be made explicit that only one study (Howell et al., 2008) was done purely in MT setting and none of the included studies simulated all components of the manual examination of joint motion. Three studies (Howell et al., 2008; Tong et al., 2018; Ullrich \& Kuhlen, 2012) used mixed methods study design, and one study (Khaled et al., 2003) used a quantitative study design. Studies were conducted in Germany ( $n=2)$ (Khaled et al., 2003; Ullrich \& Kuhlen, 2012), the USA ( $n=1)$ (Howell et al., 2008) and China ( $n=1)$ (Tong et al., 2018). Table 3 presents a summary of excluded studies (with reasons).

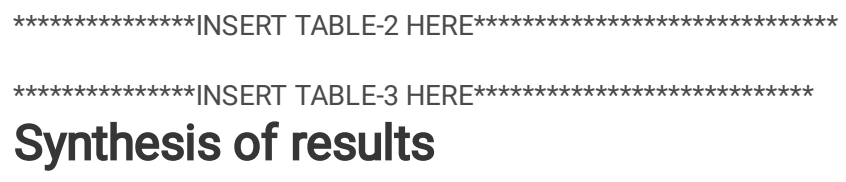

The studies included in the review were scrutinized to understand at which level(s) they contributed to the Bloom's taxonomy. All included outcomes met understanding, applying, analysing and evaluating levels of Blooms taxonomy; however, no outcomes met the 'creating' level of Bloom's taxonomy. Further, we explored secondary outcomes such as the key barriers and facilitators for utilizing 3D technologies in MT practice and educational settings. A narrative synthesis approach was undertaken for this purpose. The main findings were classified into the following key concepts: (1) perception of tissue stiffness, (2) improved student self-efficacy in performing MT techniques, and (3) barriers and facilitators for utilizing 3D technologies.

\section{Perception of tissue stiffness}

Two studies measured the effectiveness of 3D technologies in improving perception of tissue stiffness (Howell et al., 2008; Tong et al., 2018). In one study, the researchers developed a VR with magnetic levitation haptic device for augmenting tissue stiffness perception in a natural manner based on electromagnetic principles. Those authors compared the new device with a Phantom Omni device to distinguish objects of different stiffness and to detect tissue abnormality of 6 different kidney models. The findings demonstrated that VR with magnetic levitation haptic device enhanced palpatory skills of the participants, not only to distinguish different tissue stiffness but also to correctly detect tissue abnormality in the virtual environment (Tong et al., 2018). In another study, the researchers developed a virtual haptic back (VHB) which presented to users, both haptically and geographically (by feel and sight), the simulation of the contours and the tissue textures of the human back. The tissue texture was measured as tissue compliance (the inverse of stiffness) with a PHANTOM 3.0 haptic interface (SensAble Technologies, Woburn, MA) used as a force-displacement probe. Participants' (112 first year osteopathic students) palpatory performance were measured with the PHANTOM 3.0 device before and after 6 sessions with the VHB. Webber's fraction (compliance difference between the abnormal region and the adjacent normal region) was used to measure the detection of tissue compliance. The results showed that using VHB not only improved palpatory performance in detection of tissue compliance (Webber fraction: 28\% (pre) to 14\% (post)) but the average time per localization of 
abnormal tissue fell from $39 \mathrm{~s}$ to $17 \mathrm{~s}$. In turn, an overall measure of performance that included both accuracy and speed of palpation were also shown to improve continuously resulting in the mastery of palpatory process (Howell et al., 2008).

\section{Increased student satisfaction and self-efficacy}

Three studies (Howell et al., 2008; Tong et al., 2018; Ullrich \& Kuhlen, 2012) measured the overall acceptance of the simulators (VR with haptic device, VR with magnetic levitation device and VHB) using subjective questionnaires. Simulations received mostly positive ratings and an improvement in performance was accompanied with an increased self-efficacy of students. Tong et al. (2018) measured the perceived quality of experience (QoE) for tissue stiffness perception, which is related to subjective user experience with a service or an application. The QoE is based on four factors namely (1) sensory perception (how much the haptic device contributed to augmenting the stiffness perception of tissue), (2) realism (how much the virtual environment is realistic), (3) comfort (how comfortable the haptic device is to use), and (4) satisfaction (whether the user prefers to use the device). Each factor was evaluated by questions rated on a 5point scale. The mean value was calculated and QoE was computed as the sum of these 4 factors. It was found that the magnetic levitation haptic device increased the QoE, especially the 'sensory' component enabling the interaction consistent with the user's habits of the real world. Howell et al., (2008) surveyed the students who used the VHB to understand whether improved performance on the VHB translated into better palpatory diagnosis of real patients. Most participants in their study reported that the VHB was helpful and improved palpation on real patients thereby improving their confidence and self-efficacy. Ulrich and Kuhlen (2012) proposed a novel approach to enable haptic palpation interaction for virtual reality-based medical simulators. a post-test questionnaire with a 7-point Likert scale ( 1 = strongly agree, to 7 = strongly disagree). The items were grouped into controls and interface, visuals, simulation, haptics of the simulator, acceptance and detailed questions about the palpation pad and palpation interaction. The study found that the overall acceptance of the simulator got mostly positive ratings.

\section{Facilitators and barriers for utilizing 3D technologies}

Our review identified several facilitators for using 3D technologies. Often students regard these technologies as a fun and meaningful way to learn (Howell et al., 2008; Tong et al., 2018; Ullrich \& Kuhlen, 2012). After the initial training, the applications were perceived to be easy to use which is an important factor in trialling new technologies (Howell et al., 2008). A key advantage of using the 3D technologies was the many opportunities for students to practice their skills (Howell et al., 2008). Through repeated practice using 3D technologies, the students were not only able to integrate physical and cognitive tasks but were able to transfer their training to real life, thereby, improving their self-efficacy in clinical use of the technology (Howell et al., 2008; Tong et al., 2018).

Our review identified several barriers for using 3D technologies in MT education including (1) problems with hardware devices, (2) learning time, (3) realism, and (4) resource related issues. A key barrier for using 3D technology was the difficulty of using a hardware interface, which some participants perceived as being 'intimidating'. Further, head mount devices can be also intimidating to a non-technical user and could be potentially non-ergonomic for longer training sessions (Ullrich \& Kuhlen, 2012). Participants across studies also reported that the time taken to learn and familiarise themselves with the software/hardware and how to control the simulators can be long and may act as a barrier to use 3D technologies (Howell et al., 2008; Tong et al., 2018; Ullrich \& Kuhlen, 2012). A key aspect of a 3D technology is to feel as natural as possible, which is known as 'realism' (Tong et al., 2018). Good systems achieve realism with minimal effort by the user even without prior training (Ullrich \& Kuhlen, 2012). Minimal or lack of realism was identified as a barrier for using 3D technologies (Tong et al., 2018; Ullrich \& Kuhlen, 2012). On the other hand, solutions that can provide high tactile realism are prone to material deterioration from repeated use. This incurs much cost and questions about sustainability may deter potential users from utilizing these technologies (Ullrich \& Kuhlen, 2012).

\section{Discussion}

\section{Summary}

Our review found that there are no AR, VR or mixed applications that specifically serve the needs of MT education in relation to joint motion assessment, but applications are available that can be readily used or potentially adapted to train skills of tissue palpation. Our findings suggest that 3D technologies enhance palpation skills not only to distinguish different tissue stiffness but also to detect tissue abnormality in the virtual environment. Repeated practice and familiarity enabled the users of 3D technologies to become faster at localizing the abnormalities, thereby improving their physical assessment in a virtual and an actual clinical environment. In turn, student self-efficacy and satisfaction of using 3D technologies also increased. Nevertheless, various barriers and facilitators were identified for utilizing 3D technologies that may be relevant to consider while using these technologies in musculoskeletal practice.

To our knowledge, this is the first scoping review to summarize the literature on the current usage of 3D digital technologies (emulating virtual, augmented or mixed reality environments) and to identify barriers and facilitators of utilizing such technologies that are relevant to MT. Our review found that palpatory performance improved after a few sessions with 3D technologies. These results are not surprising as improvement in performance comes with practice in any task and consistent with previous findings (Khaled et al., 2003; Tong et al., 2018; Ullrich \& Kuhlen, 2012). Additional features such as bimanual interactions that enable two tasks to be done at the same time and "sensor" hands that interact with the skin surface of the virtual patient providing rich haptic feedback (Ullrich \& Kuhlen, 2012). Taken together, findings suggest that users of 3D technologies might become faster at localizing the abnormalities, improve physical assessment skills and show increased satisfaction with 3D technologies.

Several barriers for using 3D technologies were identified which are consistent with existing literature (Driscoll et al., 2019; Evans, Douglas, Bailey, \& Moffatt, 2019; Muangpoon, Haghighi Osgouei, Escobar-Castillejos, Kontovounisios, \& Bello, 2020; Pritchard, Blackstock, Nestel, \& Keating, 2016; Rossettini et al., 2017; Ullrich \& Kuhlen, 2012). Key barriers include issues with hardware devices and the time required to learn the technology (Howell et al., 2008; Khaled et al., 2003; Tong et al., 2018; Ullrich \& Kuhlen, 2012). Addressing these barriers may require collaborative approach from clinicians and developers to design 3D technologies for the specific requirements of MT education (Glegg \& Levac, 2018). 
In future designs of technologies for MT applications, educators could share the clinical reasoning behind a physical assessment procedure enabling the developer to integrate the software parameters that control the degree of physical tasks and challenges to meet the assessment needs. This step may be crucial as physical assessment procedures vary depending on the anatomical area of interest. For example, the physical assessment parameters required for assessing a shoulder joint will be different from that of assessing an ankle joint and so on. Whilst it is important to provide flexibility for users, it is also important not to overwhelm students/users with abundant decision-making requirement or decreased ease of use, which may reduce the sense of intimidation (Glegg \& Levac, 2018). Although participants across studies expressed satisfaction using 3D technologies, literature has shown that motivation of users of 3D technologies often declines over time. Hence, the technologies designed for MT education may need to consider attributes that sustain motivation and engagement of learners over a longer period (Khan et al., 2019).

\section{Strengths and limitations}

One of the strengths was that we used a comprehensive search strategy to maximize opportunity for locating all relevant studies representing the phenomena of interest. We expect minimal biases in extracting and reporting of data. Only four eligible studies (Howell et al., 2008; Khaled et al., 2004; Tong et al., 2018; Ullrich \& Kuhlen, 2012) were included in narrative data synthesis which would account for an overall low certainty of current evidence in this area. The small number of studies included however may represent the lack of research done in this area. We only included English language studies and omitted gray literature which might be seen as a limitation. We have precluded methodological quality or risk of bias assessment of the included studies as it is not a mandatory requirement for a scoping review.

Our findings suggest that 3D technologies may improve palpatory performance. However, it must be noted that only one study (Howell et al., 2008) was done purely in an MT setting. Hence, the exact role of 3D technologies in enhancing MT assessments remains unknown. Further, an objective demonstration of improvement in palpatory performance in a clinical setting would provide robust evidence for using such technologies in MT education. Further, the role of 3D technologies in the assessment of clinical reasoning and/or providing feedback of physical assessment for MT students remains unclear. Finally, it has to be made explicit that 3D technologies may augment MT education, but cannot replace face-to-face teaching completely. Nevertheless it could also be argued that such technologies could play an important role where face-to-face teaching may not be possible (e.g., COVID pandemic).

\section{Implications for MT practice/education and research}

While these technologies can provide high tactile realism, the hardware devices can be challenging to adjust to and can be prone to material deterioration from repeated use (Fitzgerald, Denning, Vaughan, Fleischmann, \& Jolly, 2019). This may incur additional costs which may deter educational institutions to trial these technologies. While many of the existing technologies are not directly relevant to MT requirements, the technology is there to develop relevant applications. Our review found that VR with haptic feedback was better than normal simulators in enhancing palpatory skills and physical assessment skills in students, because of full control over the environment.

Successful palpation requires skills such as sense of texture, tissue compliance/stiffness, lateral motions and high DOF. Studies included in the review often incorporated 3 DOF movements which may be adequate However, future studies could trial devices that might allow for 6 DOF movements (Ullrich \& Kuhlen, 2012). Recent advances such as hand exoskeletons that provide more DOF and mimic the hand movements of the operator may be of particular interest to students learning manual therapy as these may replicate and/or meet the sophisticated requirements to teach/learn complex manual techniques for which palpation skills may be mandatory.

\section{Declarations}

\section{Funding}

The study was not funded by any organization or individual.

\section{Competing interests}

The authors declare no competing interests.

\section{References}

Arksey, H., \& O'Malley, L. (2005). Scoping studies: towards a methodological framework. International Journal of Social Research Methodology, 8(1), 19-32. doi:10.1080/1364557032000119616

Brigham, T. J. (2017). Reality Check: Basics of Augmented, Virtual, and Mixed Reality. Medical Reference Services Quarterly, 36(2), 171-178. doi:10.1080/02763869.2017.1293987

Bugaj, T. J., \& Nikendei, C. (2016). Practical Clinical Training in Skills Labs: Theory and Practice. GMS journal for medical education, $33(4)$, Doc63-Doc63. doi:10.3205/zma001062

Driscoll, J., Jarrett, C., Page, R., Worsley, R., Cheung, Y., \& Dimmock, V. (2019). SC13 A report on a novel simulation intervention to up-skill adult trained physiotherapists to provide out of hours support to paediatric respiratory patients. BMJ Simulation \& Technology Enhanced Learning, 5(Suppl 2).

doi:http://dx.doi.org/10.1136/bmjstel-2019-aspihconf.46 
Easton, G., Stratford-Martin, J., \& Atherton, H. (2012). An appraisal of the literature on teaching physical examination skills. Education for Primary Care, 23(4), 246-254. doi:10.1080/14739879.2012.11494117

Evans, L., Douglas, E., Bailey, P., \& Moffatt, F. (2019). P17 Developing undergraduate physiotherapy skills in assessing the acutely ill patient using high fidelity simulation. BMJ Simulation \& Technology Enhanced Learning, 5(Suppl 2). doi:http://dx.doi.org/10.1136/bmjstel-2019-aspihconf.122

Farshid, M., Paschen, J., Eriksson, T., \& Kietzmann, J. (2018). Go boldly!: Explore augmented reality (AR), virtual reality (VR), and mixed reality (MR) for business. Business Horizons, 61(5), 657-663. doi:https://doi.org/10.1016/j.bushor.2018.05.009

Fitzgerald, K. M., Denning, T., Vaughan, B. R., Fleischmann, M. J., \& Jolly, B. C. (2019). Simulation can offer a sustainable contribution to clinical education in osteopathy. Chiropractic \& Manual Therapies, 27(1), N.PAG-N.PAG. doi:http://dx.doi.org/10.1186/s12998-019-0252-0

Glegg, S. M. N., \& Levac, D. E. (2018). Barriers, Facilitators and Interventions to Support Virtual Reality Implementation in Rehabilitation: A Scoping Review. Pm r, 10(11), 1237-1251.e1231. doi:http://dx.doi.org/10.1016/j.pmrj.2018.07.004

Hamilton, D., McKechnie, J., Edgerton, E., \& Wilson, C. (2020). Immersive virtual reality as a pedagogical tool in education: a systematic literature review of quantitative learning outcomes and experimental design. Journal of Computers in Education. doi:10.1007/s40692-020-00169-2

Howell, J. N., Conatser, R. R., Williams, R. L., 2nd, Burns, J. M., \& Eland, D. C. (2008). The virtual haptic back: a simulation for training in palpatory diagnosis. BMC Medical Education, 8, 14. doi:http://dx.doi.org/10.1186/1472-6920-8-14

Huijbregts, P. A. (2011). 48 - Manual Therapy. In T. A. Lennard, S. Walkowski, A. K. Singla, \& D. G. Vivian (Eds.), Pain Procedures in Clinical Practice (Third Edition) (pp. 573-596). Saint Louis: Hanley \& Belfus.

Khaled, W., Ermert, H., Bruhns, O., Boese, H., Baumann, M., Monkman, G. J., . . Freimuth, H. (2003). A haptic sensor-actor-system based on ultrasound elastography and electrorheological fluids for virtual reality applications in medicine. Student Health Technolgical Information, 94, 144-150.

Khaled, W., Reichling, S., Bruhns, O. T., Boese, H., Baumann, M., Monkman, G., . . Ermert, H. (2004). Palpation imaging using a haptic system for virtual reality applications in medicine. Student Health Technological Information, 98, 147-153. doi:http://dx.doi.org/10.1142/9789812702678_0055

Khan, T., Johnston, K., \& Ophoff, J. (2019). The Impact of an Augmented Reality Application on Learning Motivation of Students. Advances in HumanComputer Interaction, 2019, 7208494. doi:10.1155/2019/7208494

Kirkman, M. A., Ahmed, M., Albert, A. F., Wilson, M. H., Nandi, D., \& Sevdalis, N. (2014). The use of simulation in neurosurgical education and training. Journal of Neurosurgery 121(2), 228. doi:http://dx.doi.org/10.3171/2014.5.Jns131766

Kotsis, S. V., \& Chung, K. C. (2013). Application of the "see one, do one, teach one" concept in surgical training. Plastic and reconstructive surgery, 131(5), 11941201. doi:10.1097/PRS.0b013e318287a0b3

Lenchus, J. D. (2010). End of the "see one, do one, teach one" era: the next generation of invasive bedside procedural instruction. The Journal of the American Osteopathic Association, 110(6), 340-346.

Loh, M. S., Gevitz, N., Gilliar, W. G., lacono, L. M., Jung, M.-K., Krishnamachari, B., \& Amsler, K. (2015). Use of a Novel Assay to Measure Pre-to Posttraining Palpatory Skills of First-Year Osteopathic Medical Students. The Journal of the American Osteopathic Association, 115(1), 32-40. doi:10.7556/jaoa.2015.005

Michels, M. E. J., Evans, D. E., \& Blok, G. A. (2012). What is a clinical skill? Searching for order in chaos through a modified Delphi process. Medical Teacher, 34(8), e573-e581. doi:10.3109/0142159x.2012.669218

Monroy, M., Oyarzabal, M., Ferre, M., Campos, A., \& Barrio, J. (2008). MasterFinger: Multi-finger Haptic Interface for Collaborative Environments, Berlin, Heidelberg.

Muangpoon, T., Haghighi Osgouei, R., Escobar-Castillejos, D., Kontovounisios, C., \& Bello, F. (2020). Augmented Reality System for Digital Rectal Examination Training and Assessment: System Validation. Journal of Medical Internet Research, 22(8), e18637. doi:http://dx.doi.org/10.2196/18637

Pacchierotti, C., Chinello, F., Malvezzi, M., Meli, L., \& Prattichizzo, D. (2012). Two Finger Grasping Simulation with Cutaneous and Kinesthetic Force Feedback, Berlin, Heidelberg.

Peters, M. D. J., Marnie, C., Tricco, A. C., Pollock, D., Munn, Z., Alexander, L., . . Khalil, H. (2020). Updated methodological guidance for the conduct of scoping reviews. JBI Evidence Synthesis, 18(10). Retrieved from https://journals.Iww.com/jbisrir/Fulltext/2020/10000/Updated_methodological_guidance_for_the_conduct_of.4.aspx

Pritchard, S. A., Blackstock, F. C., Nestel, D., \& Keating, J. L. (2016). Simulated Patients in Physical Therapy Education: Systematic Review and Meta-Analysis. Physical Therapy, 96(9), 1342-1353. doi:http://dx.doi.org/10.2522/ptj.20150500

Ramirez, T. V. (2017). On Pedagogy of Personality Assessment: Application of Bloom's Taxonomy of Educational Objectives. Journal of Personality Assessment, 99(2), 146-152. doi:http://dx.doi.org/10.1080/00223891.2016.1167059

Page 7/13 
Rodriguez-Paz, J. M., Kennedy, M., Salas, E., Wu, A. W., Sexton, J. B., Hunt, E. A., \& Pronovost, P. J. (2009). Beyond "see one, do one, teach one": toward a different training paradigm. Quality and Safety in Health Care, 18(1), 63-68. doi:10.1136/qshc.2007.023903

Rossettini, G., Rondoni, A., Palese, A., Cecchetto, S., Vicentini, M., Bettale, F., . . Testa, M. (2017). Effective teaching of manual skills to physiotherapy students: a randomised clinical trial. Medical Education, 51(8), 826-838. doi:10.1111/medu.13347

Tong, Q., Yuan, Z., Liao, X., Zheng, M., Yuan, T., \& Zhao, J. (2018). Magnetic Levitation Haptic Augmentation for Virtual Tissue Stiffness Perception. IEEE Trans Vis Comput Graph, 24(12), 3123-3136. doi:http://dx.doi.org/10.1109/tvcg.2017.2772236

Ullrich, S., \& Kuhlen, T. (2012). Haptic palpation for medical simulation in virtual environments. IEEE Trans Visual Computer Graph, 18(4), 617-625.

doi:http://dx.doi.org/10.1109/tvcg.2012.46

\section{Tables}

\section{Table 1 Search Strategy}

\begin{tabular}{|c|c|c|}
\hline Participants & Interventions & Outcomes \\
\hline $\begin{array}{l}\text { physiotherap*, 'physical } \\
\text { therap*', 'manual } \\
\text { therap*', therap*, } \\
\text { 'osteopath*', } \\
\text { 'chiroprac*', student*, } \\
\text { trainee*, } \\
\text { undergraduate*, } \\
\text { graduate, postgraduate, } \\
\text { profess*, academi* }\end{array}$ & $\begin{array}{l}\text { leducat*, learn*, skill* develop*, teach*, 'm-learning', 'mobile learning', } \\
\text { 'eLearning', 'E-learning', 'digital app*', 'mobile app*', 'smartphone app*', '3D', } \\
\text { 'three-dimensio*', '3-dimensio*', 'augmented reality', 'virtual reality', 'mixed } \\
\text { reality', 'human-computer interaction', 'user computer interface', 'immersion', } \\
\text { 'augmented reality', 'virtual environment', 'virtual world', 'head mount display', } \\
\text { 'virtual classroom', 'virtual training', 'education', 'manual therapy education', } \\
\text { 'manual therapy practice', 'manual therapy', 'musculoskeletal*','MSK', } \\
\text { 'musculoskeletal practice', 'training', tool* }\end{array}$ & $\begin{array}{l}\text { learn*, skill* develop*, } \\
\text { skill* practic*, feedback*, } \\
\text { skill*, performance*, } \\
\text { competenc*, clinical skill*, } \\
\text { assessment, evaluat*, } \\
\text { apprais*, measure*, } \\
\text { remembe*, understan*, } \\
\text { appl*, analy*, evaluat*, } \\
\text { create* }\end{array}$ \\
\hline
\end{tabular}

Table 2 Characteristics of included studies 


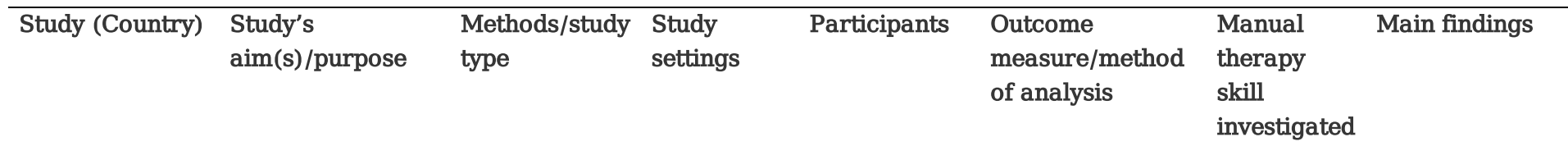

\begin{tabular}{|c|c|c|}
\hline $\begin{array}{l}\text { Khaled et al. } \\
2004 \text { (Germany) }\end{array}$ & $\begin{array}{l}\text { Develop a haptic } \\
\text { sensor actuator } \\
\text { system to } \\
\text { visualize and } \\
\text { reconstruct } \\
\text { mechanical } \\
\text { properties of } \\
\text { tissue using } \\
\text { ultrasonic } \\
\text { elastography and } \\
\text { a haptic display } \\
\text { with } \\
\text { electrorheological } \\
\text { fluids. }\end{array}$ & $\begin{array}{l}\text { Investigation } \\
\text { of various } \\
\text { modifications } \\
\text { on the haptic } \\
\text { sensor } \\
\text { actuator } \\
\text { system }\end{array}$ \\
\hline $\begin{array}{l}\text { Tong et al. } 2018 \\
\text { (China) }\end{array}$ & $\begin{array}{l}\text { The magnetic } \\
\text { levitation haptic } \\
\text { device can } \\
\text { provide accurate } \\
\text { tissue stiffness } \\
\text { perception } \\
\text { augmentation } \\
\text { with natural and } \\
\text { immersive haptic } \\
\text { interaction. }\end{array}$ & $\begin{array}{l}\text { Quantitative } \\
\text { and } \\
\text { qualitative } \\
\text { experiments } \\
\text { followed by } \\
\text { perceived } \\
\text { quality of } \\
\text { experience } \\
\text { questionnaire }\end{array}$ \\
\hline
\end{tabular}

Ullrich and

Kuhlen. 2012

(Germany)
Howell et al. 2008 (USA)
Enable haptic palpation interaction for virtual realitybased medical simulators

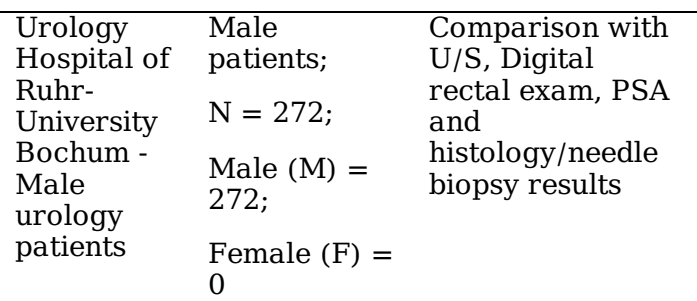

$\begin{array}{ll}\begin{array}{ll}\text { University } \\ \text { research } \\ \text { laboratory }\end{array} & \begin{array}{l}\text { University } \\ \text { students } \\ \text { teachers; }\end{array} \\ & \mathrm{N}=22 \\ & \mathrm{M}=13 ; \\ & \mathrm{F}=9\end{array}$

Post-test questionnaire and formal interview

Determine the value of Virtual Haptic Back (VHB) as a teaching aid in initial phases of learning
Pre and post anonymous evaluation questionnaires with 6 training sessions in between with accuracy

$\begin{array}{ll}\begin{array}{ll}\text { University } \\ \text { virtual } \\ \text { reality } \\ \text { centre }\end{array} & \text { Anaesthetists } \\ & \mathrm{N}=40 ; \\ & \text { Residents }= \\ & \mathrm{M}=10 ; \\ & \mathrm{F}=13 ; \\ & \text { Consultants } \\ & =17 ; \\ & \mathrm{M}=13 ; \\ & \mathrm{F}=4\end{array}$

University $\quad 1^{\text {st }}$ yr College of Osteopathic Osteopathic Medical Medicine students; $\mathrm{N}=89$
Qualitative analysis.

The quality of experience questionnaire based on four factors namely (1) sensory perception (2) realism (3) comfort and (4) satisfaction. Each factor was evaluated by questions rated on a 5-point scale.

\section{Subjective and} correlation analysis.

post-test questionnaire with a 7-point Likert scale $(1=$ strongly agree to 7 = strongly disagree). The items were grouped into interface, visuals, simulation, haptics of the simulator, acceptance, pad and palpation interaction.

Qualitative and quantitative analysis.

Webber's fraction (compliance difference between the controls and

\author{
Quality of Most users can \\ experience clearly and \\ for tissue immersively \\ stiffness \\ perception \\ perceive different \\ tissue stiffness and \\ easily detect the \\ tissue abnormality. \\ Magnetic levitation \\ haptic device can \\ provide accurate \\ tissue stiffness \\ perception \\ augmentation with \\ natural and \\ immersive haptic \\ interaction
}

Tissue palpation

The haptic palpation with the simulated deformable tissue and the hardware extension was rated mostly positively by medical experts.

Palpation of tissue compliance

Students improved in accuracy and speed of diagnosis with practice. The VHB has potential value as a teaching aid for students in the initial phase of 
palpatory

diagnosis

evaluation at

session (gender not specified) abnormal region

and the adjacent

normal region)

was used to

measure the

detection of

tissue

compliance. learning palpatory

diagnosis.

Table 3 Characteristics of excluded studies 


\begin{tabular}{llllll}
\hline $\begin{array}{l}\text { Study } \\
\text { (Country) }\end{array}$ & $\begin{array}{l}\text { Study's } \\
\text { aim(s)/purpose }\end{array}$ & Methods/ & Study settings & Participants & $\begin{array}{l}\text { Outcome } \\
\text { measure/method } \\
\text { study type }\end{array}$ \\
& & & & $\begin{array}{l}\text { Reason } \\
\text { of analysis }\end{array}$
\end{tabular}

\begin{tabular}{|c|c|c|c|c|c|c|c|}
\hline $\begin{array}{l}\text { Evans } 2019 \\
\text { (UK) }\end{array}$ & $\begin{array}{l}\text { Addition of } \\
\text { simulation } \\
\text { training to } \\
\text { traditional } \\
\text { education } \\
\text { programme } \\
\text { increases } \\
\text { student } \\
\text { confidence }\end{array}$ & $\begin{array}{l}\text { Simulated } \\
\text { scenarios } \\
\text { supported by } \\
\text { facilitated } \\
\text { debriefs } \\
\text { taken at } 4 \\
\text { phases }\end{array}$ & $\begin{array}{l}\text { Multi-professional } \\
\text { faculty }\end{array}$ & $\begin{array}{l}\text { Physiotherapy } \\
\text { students; } \\
\mathrm{N}=13 \\
\text { (gender not } \\
\text { specified) }\end{array}$ & $\begin{array}{l}\text { Qualitative and } \\
\text { quantitative } \\
\text { analysis }\end{array}$ & $\begin{array}{l}\text { Students } \\
\text { reported } \\
\text { increased } \\
\text { confidence. } \\
\text { Further follow- } \\
\text { up is required to } \\
\text { explore potential } \\
\text { for confidence } \\
\text { decay. }\end{array}$ & $\begin{array}{l}\text { Not rel } \\
\text { manual } \\
\text { therapy } \\
\text { assessr } \\
\text { treatme } \\
\text { educati } \\
\text { no reler } \\
\text { applica }\end{array}$ \\
\hline $\begin{array}{l}\text { Driscoll } \\
2019 \text { (UK) }\end{array}$ & $\begin{array}{l}\text { Improved risk } \\
\text { assessment for } \\
\text { acute } \\
\text { paediatric } \\
\text { respiratory } \\
\text { disease }\end{array}$ & $\begin{array}{l}\text { One day } \\
\text { simulation } \\
\text { course with } \\
\text { lectures with } \\
\text { pre- and } \\
\text { post-course } \\
\text { assessment }\end{array}$ & University hospital & $\begin{array}{l}\text { Physiotherapists; } \\
\mathrm{N}=21 \\
\text { (no gender } \\
\text { specified) }\end{array}$ & $\begin{array}{l}\text { Qualitative and } \\
\text { quantitative } \\
\text { analysis }\end{array}$ & $\begin{array}{l}\text { Participants } \\
\text { improved in all } \\
\text { areas except } \\
\text { risk assessment. } \\
\text { Self-efficacy } \\
\text { scores } \\
\text { measuring } \\
\text { confidence } \\
\text { improved across } \\
\text { all parameters }\end{array}$ & $\begin{array}{l}\text { Not rel€ } \\
\text { MT ass } \\
\text { or treat } \\
\text { educati }\end{array}$ \\
\hline $\begin{array}{l}\text { Johnston } \\
2018 \\
\text { (Australia) }\end{array}$ & $\begin{array}{l}\text { Explore } \\
\text { Student } \\
\text { attitudes } \\
\text { towards } \\
\text { simulated } \\
\text { learning } \\
\text { experiences as } \\
\text { a preparatory } \\
\text { component of } \\
\text { an } \\
\text { introductory } \\
\text { clinical } \\
\text { placement }\end{array}$ & $\begin{array}{l}\text { Pre- and } \\
\text { Post- } \\
\text { anonymous } \\
\text { surveys }\end{array}$ & $\begin{array}{l}\text { Clinical placements in } \\
\text { the public and private } \\
\text { sectors }\end{array}$ & $\begin{array}{l}2^{\text {nd }} \text { year } \\
\text { physiotherapy } \\
\text { students; } \\
\mathrm{N}=43 ; \\
\text { Male }(\mathrm{M})=18 ; \\
\text { Female }(\mathrm{F})=25\end{array}$ & $\begin{array}{l}\text { Qualitative and } \\
\text { quantitative } \\
\text { data analysis }\end{array}$ & $\begin{array}{l}\text { All responses } \\
\text { were more } \\
\text { positive at the } \\
\text { end of } \\
\text { placement than } \\
\text { at the } \\
\text { commencement } \\
\text { of the project, } \\
\text { but generally } \\
\text { less positive } \\
\text { than at the } \\
\text { completion of } \\
\text { the simulated } \\
\text { learning } \\
\text { experience } \\
\text { week. }\end{array}$ & $\begin{array}{l}\text { Not rel } \\
\text { to MT } \\
\text { assessn } \\
\text { treatme } \\
\text { educati }\end{array}$ \\
\hline
\end{tabular}

\begin{tabular}{|c|c|c|c|c|c|}
\hline $\begin{array}{l}\text { Johannesson, } \\
2013 \\
\text { (Sweden) }\end{array}$ & $\begin{array}{l}\text { Investigate the } \\
\text { students' } \\
\text { experiences } \\
\text { and thoughts } \\
\text { about their } \\
\text { learning in } \\
\text { simulation } \\
\text { skills training }\end{array}$ & $\begin{array}{l}\text { Semi- } \\
\text { structured } \\
\text { interviews } \\
\text { (pairs) }\end{array}$ & $\begin{array}{l}\text { Undergraduate nursing } \\
\text { clinical skills centre }\end{array}$ & $\begin{array}{l}\text { 3rd year nursing } \\
\text { students; } \\
\mathrm{N}=10 \\
\mathrm{M}=0 \\
\mathrm{~F}=10\end{array}$ & $\begin{array}{l}\text { inductive } \\
\text { content analysis }\end{array}$ \\
\hline
\end{tabular}

The students

Task (C related the task insertio to earlier relevan experiences, used sensory information, tested themselves and practised techniques in a hands-on fashion, and reflected in and on action. The simulator was seen as a facilitator to learning the manual skills.

Ohtake 2013 Examine the (USA)

effect of simulationbased management of critical care patients in an ICU setting on confidence and satisfaction levels in physical therapy students.
Pre- and post-test survey
University Quasiexperimental design $1^{\text {st }}$ year Doctor of Physical

Therapy students;

$\mathrm{N}=43$

(gender not specified)
Qualitative and quantitative data analysis
The simulation improved physical therapist student confidence in a number of areas and was associated with high student satisfaction. Limitations were that it was a small sample from one university with no control group included.
Setting: not rele MT 


\begin{tabular}{|c|c|c|c|c|c|c|c|}
\hline $\begin{array}{l}\text { Pritchard } \\
2016 \\
\text { (Australia) }\end{array}$ & $\begin{array}{l}\text { Evaluation of } \\
\text { the effects of } \\
\text { Simulated } \\
\text { Patients on } \\
\text { professional } \\
\text { (entry level) } \\
\text { physical } \\
\text { therapy } \\
\text { education }\end{array}$ & $\begin{array}{l}\text { Online } \\
\text { search of } \\
\text { relevant } \\
\text { literature }\end{array}$ & Online research & $\begin{array}{l}\text { Peer reviewed } \\
\text { articles in } \\
\text { English }\end{array}$ & $\begin{array}{l}\text { Qualitative and } \\
\text { quantitative } \\
\text { data analysis }\end{array}$ & $\begin{array}{l}\text { SPs appear to } \\
\text { have an effect } \\
\text { comparable to } \\
\text { alternative } \\
\text { educational } \\
\text { strategies on } \\
\text { development of } \\
\text { physical therapy } \\
\text { clinical practice } \\
\text { competencies, } \\
\text { although an } \\
\text { economic } \\
\text { analysis should } \\
\text { be conducted. }\end{array}$ & $\begin{array}{l}\text { A meta- } \\
\text { analysis } \\
\text { simulati } \\
\text { patients } \\
\text { phsyiot] } \\
\text { educati } \\
\text { related } \\
\text { aims/ok } \\
\text { of the c } \\
\text { review }\end{array}$ \\
\hline $\begin{array}{l}\text { Ikram } 2017 \\
\text { (UK) }\end{array}$ & $\begin{array}{l}\text { Sought to } \\
\text { compare the } \\
\text { simulation- } \\
\text { based } \\
\text { perceptions of } \\
\text { physiotherapy, } \\
\text { medical and } \\
\text { nursing } \\
\text { students before } \\
\text { and after a } \\
\text { high-fidelity } \\
\text { Simulation } \\
\text { inter- } \\
\text { professional } \\
\text { session }\end{array}$ & $\begin{array}{l}\text { KidSIM } \\
\text { ATTITUDES } \\
\text { questionnaire }\end{array}$ & $\begin{array}{l}\text { physiotherapy, medical } \\
\& \text { nursing } \\
\text { undergraduate } \\
\text { students }\end{array}$ & $\begin{array}{l}\mathrm{N}=145 \\
26 \text { physio, } 54 \\
\text { medical, } 65 \\
\text { nursing }\end{array}$ & $\begin{array}{l}\text { Comparison of } \\
\text { pre and post } \\
\text { questionnaire } \\
\text { responses }\end{array}$ & $\begin{array}{l}\text { physiotherapy } \\
\text { students had } \\
\text { significantly less } \\
\text { positive } \\
\text { perceptions of } \\
\text { the relevance of } \\
\text { simulation and } \\
\text { communication } \\
\text { compared to } \\
\text { medical and } \\
\text { nursing students } \\
\text { and less positive } \\
\text { perceptions } \\
\text { regarding the } \\
\text { opportunities in } \\
\text { interprofessional } \\
\text { education roles } \\
\text { and } \\
\text { responsibilities } \\
\text { and situation } \\
\text { awareness } \\
\text { compared to } \\
\text { nursing students } \\
\text { only }\end{array}$ & $\begin{array}{l}\text { No rele' } \\
\text { applica' }\end{array}$ \\
\hline
\end{tabular}

\section{Figures}


Figure 1: PRISMA flow diagram of included studies

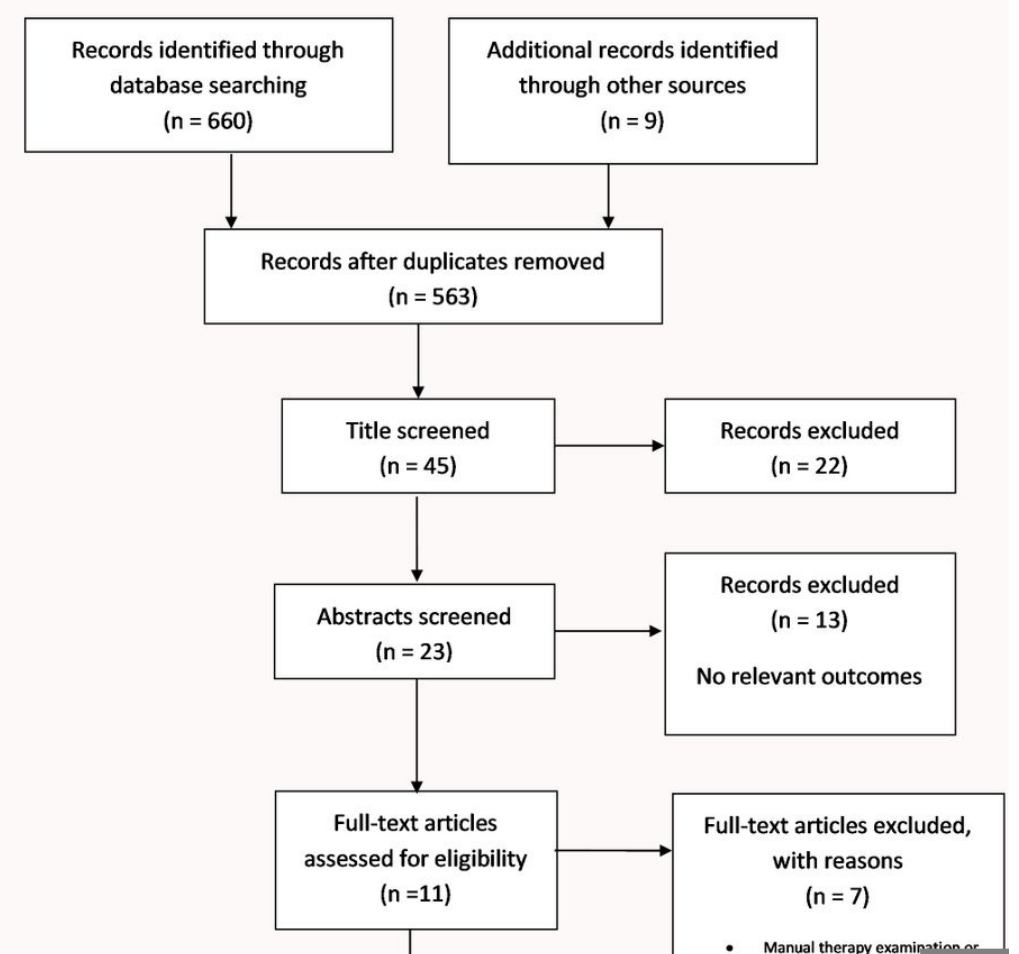

Figure 1

PRISMA Flow Diagram of Included Studies 